\title{
READINESS FOR INDUSTRY 4.0 RELATED CHANGES: A CASE STUDY OF THE VISEGRAD FOUR
}

\author{
Kornelia Lazanyi ${ }^{1, \mathrm{a}, *}$ and Maya Lambovska ${ }^{2, \mathrm{~b}}$ \\ ${ }^{1}$ Keleti Faculty of Business and Management, Obuda University in Budapest, Hungary \\ ${ }^{2}$ Department of Management, University of National and World Economy, Sofia, Bulgaria \\ alazanyi.kornelia@kgk.uni-obuda.hu, ${ }^{b}$ mlambovska@abv.bg \\ *Corresponding author
}

Cite as: Lazanyi, K., Lambovska, M. (2020). Readiness for industry 4.0 related changes: A case study of the Visegrad four, Ekonomicko-manazerske spektrum, 14(2), 100-113.

Available at: dx.doi.org/10.26552/ems.2020.2.100-113.

Received: 15 September 2020; Received in revised form: 30 October 2020; Accepted: 14 November 2020; Available online: 2 December 2020

\begin{abstract}
Industrial revolution refers to a period in human history in which revolutionary scientific discoveries and inventions that affect the functioning of society as a whole take place. Changes resulting from industrial revolutions sooner or later affect all sectors of the economy. The Fourth Industrial Revolution, also known as Industry 4.0, has brought with it many changes. Industry 4.0 has spread rapidly and has become a current phenomenon. Within the theoretical part of the contribution, the authors deal with development, definition, and comparison of industrial revolutions. The aim of the contribution is to examine the readiness of the Visegrad Four countries for changes connected with Industry 4.0. Several national initiatives responding to Industry 4.0 have been launched across Europe in recent years. Their purpose is to regulate the realization of Industry 4.0 and its consequences. Almost every member state of the European Union has its own national initiative, responding to Industry 4.0. Within the practical part of the contribution, authors focused on initiatives responding to Industry 4.0 in the V4 countries. To examine the readiness of the V4 countries for the challenges related to the Fourth Industrial Revolution - Industry 4.0, secondary data - The Digital Economy and Society Index (DESI) - was used, as well as a z-score calculation. The resulting z-scores show which countries currently achieve the best results in terms of the Drivers of Production values when compared to the GDP per capita. To see how each country is doing compared to the mean value of the respective indicators, z-scores were calculated for each of them.
\end{abstract}

Keywords: industry 4.0, the fourth industrial revolution, Z-score, DESI, digitalization

JEL Classification: O14, O30, O57

\section{Introduction - Theoretical background and Literature review}

Within the theoretical part of the contribution, the authors deal with the term "industrial revolution", focusing on The Fourth Industrial Revolution, also referred to as Industry 4.0. Development, definition, and comparison of industrial revolutions are described. The term industrial revolution is defined as term used widely beyond just authors of economic publications. The term was first used in the 1920s in France in connection with the 
mechanization of the cotton industry (Cameron and Drabek, 1996) Four industrial revolutions can be distinguished, including the latest one - Industry 4.0.

\subsection{The first industrial revolution - industrialization}

The First Industrial Revolution began in the UK, its beginning dates to the second half of the 18th century. In a short period of time, several important inventions appeared, starting the transformation process. The aim of this change was to increase the physical potential of mankind by assisting them in manual labor. James Watt's invention of the steam engine played a key role in the First Industrial Revolution, and later enabled the construction of the world's first steam-powered automobile, and can therefore be considered as the beginning of the automotive industry. The First Industrial Revolution is also connected with the term industrialization. Industrialization can be defined as introduction of new technologies into the production process (Brezis and Tsiddon, 1993). Coal became the main fuel of the First Industrial Revolution and steam its main driving force. The replacement of human and animal power by steam power led increased efficiency and productivity in production and transportation. The share of industry in the added value and the number of industrial workers increased, at the expense of agriculture. Smaller workshops were replaced by or integrated into large production factories. Department stores were built instead of small shops. It can be stated that this period is associated with the foundations of large enterprises (Beaudion, 2020). The First Industrial Revolution also had a significant impact on the social environment; in the newly organized manufacturing sector, more emphasis was placed on the discipline of workers, and relations between workers became less personal and more bureaucratic. Industrialization also affected the functioning of families. A fundamental change was the separation of home from the place of work, giving rise to the need to commute. The standard of living increased, accompanied by population and GDP per capita growth. The impact of the First Industrial Revolution was enormous, bringing a fundamental change in the whole economy, as well as in the lifestyle of society (Baptista, 1999; Brezis et al., 1993). Owing to the first industrial revolution in most developed countries the population migrated from the primer - agricultural - to the second - industrial - sector. Urbanization gained an impetus never seen before, however, people did not only separate their living and working environment with this, but they also got detached from nature, and over $50 \%$ of people were not involved in providing their own sources of food. Hence their dependence increased manyfold (Szücs, 2017). On the one hand they were dependent on their employers on the other hand they were dependent on those, who supplied towns and cities with food and other basic raw materials.

\subsection{The second industrial revolution - the scientific revolution}

The Second Industrial Revolution took place between 1860 and 1918. This period is also defined as revolutionary due to the invention and subsequent introduction of a large number of new, mainly production related technologies. The main source of energy was no longer steam, but electricity. The practical significance of electrical energy is associated with Edison's invention of the light bulb. The high pace of technological change has led to transformation of the economy into the so-called "new economy". This new economy is defined by a faster pace of productivity growth. Applied science has played an important role in this period. In all areas, thanks to applied science, revolutionary results have been achieved in terms of productivity growth and efficiency. It is precisely because of the decisive role of science that the Second Industrial Revolution is also referred to as the Scientific Revolution (Amiti, 2001), Thanks to the invention of Henry Bessemer, steel became a part of everyday life and this period is also known as the age of steel. The sectors with the largest growth were the chemical and automotive 
industry. An important year was 1870, when Cincinnati installed the first assembly line at the local plant and began with division of labor, later electrified, which contributed to further rapid development of mass production. The first company to introduce serial production in its complete form was the American carmaker Ford Motor Company. Institutional changes were related to growth of education and bureaucracy. Ford was not only an educator establishing new scientific ways of management, but has also created the symbol of the second industrial revolution, the T-model. Owing to the technological development the speed and mobility of workforce has increased greatly. The world became a smaller place. While in case of the first revolution people got separated from nature, in case of the second travelling long distances on a daily basis also became natural (Mezei and Lazányi, 2018).

\subsection{The third industrial revolution - the digital revolution}

The Third Industrial Revolution began in the late 1940s. Based on the most important milestones that took place during this period, it can be divided into three stages. The first stage is connected with the invention of the transistor and the computer. Development of information and communication technologies was the main driver of the Third Industrial Revolution. It is also defined as a computer-based revolution, information technology revolution or digital revolution (Yunus, 2020). The second stage took place in the 1970s and 1980s. At that time, the biological engineering and microelectronics industries developed. The third and last stage started in the 1990s, when the commercialization of the internet began as some of the prior restrictions were lifted. This enabled introduction of the internet into households and the emergence of a global network of interconnected computers (Zheng, 2013). The Third Industrial Revolution surpassed all previous industrial revolutions in terms of the number of disciplines affected and the number of technological innovations. This was the revolution of the mind. While the first industrial revolution increased the physical capabilities, the second the speed, the third one concentrated on the cognitive capabilities and pushing its limits. Introduction of computers into practice and the ever-expanding application of information technology have led to a dramatic increase in the volume of information. The so-called "information society", sometimes referred to as the "knowledge society", has emerged. Information and knowledge have become the key elements of economic and social life. With this however, the detachment that has started owing to the previous industrial revolution grew even further. People started living (at least part of their lives) in virtual realms, cutting back on personal face-to-face interactions, limiting themselves on secondary social ties characterized only by thin trust (Lazányi et al. 2017; Diana, 2017).

\subsection{The fourth industrial revolution - industry 4.0}

The term Industry 4.0 was first used on the occasion of the Hanover Trade Fair in 2011 in connection with a project initiated by the German government to develop a high-tech strategy that would guide Germany's science and research, innovation, and their implementation in the following years. The number four (4.0) was chosen as a signal of the beginning of the fourth industrial revolution. Unlike the first three industrial revolutions, the Fourth Industrial Revolution was announced before it took place, and its possible effects on society can currently only be predicted. The name Industry 4.0 has been criticized because a great portion of the technology on which its concept is based already existed at the time of the Third Industrial Revolution. Thus, some authors refer to it as the second phase of digitization. However, despite the criticism, the concept of Industry 4.0 has spread rapidly and became a current phenomenon. Industry 4.0 focuses on end-to-end digitization of all physical assets and their integration into digital ecosystems with value chain partners. Generating, analyzing, and communicating data 
seamlessly underpins the gains promised by Industry 4.0, which networks a wide range of new technologies to create value (PricewaterhouseCoopers, 2016).

Several technological elements relate to Industry 4.0, including the cyber-physical system (CPS). The term first appeared in 2006 at a conference of the US National Science Foundation. Its author is Helen Gill. Cyber-physical systems are integrations of computation, networking, and physical processes. Embedded computers and networks monitor and control the physical processes, with feedback loops where physical processes affect computations and vice versa. The economic and societal potential of such systems is vastly greater than what has been realized, and major investments are being made worldwide to develop the technology. CPS integrates the dynamics of the physical processes with those of the software and networking, providing abstractions and modeling, design, and analysis techniques for the integrated whole. CPS relies on the Internet of Things (IoT), Internet of Services (IoS) and Big Data and Cloud computing technologies (Nazarov and Klarin, 2020; Jain and Ajmera, 2020; Beaudoin, 2000). As all these indicate, the fourth industrial revolution is the revolution of trust. While the detachment has already started with the first wave, and people got used to interacting via ICT within the third wave, the fourth wave created a need for the extension of trust toward artificial intelligence; towards non-human entities and their decisions. Trust in this regard became the proxy for control. People started to let artificial agents into every sphere of their lives and let them make (semi-)autonomous decisions (Madarász and Szikora, 2018). However, this did not happen without any backlash either. While the previous revolution triggered a life without the nature as a tranquil environment, industrial and virtual settings to loosen human relations, the fourth revolution created the phenomenon of technostress, that can barely be coped with in the inevitably intensive ICT presence of the $21^{\text {st }}$ century (Lazányi, 2016).

The Internet of Things (IoT) is a new trend in control and communication of commonly used objects with each other or with humans, mainly through wireless data and internet technologies. Such interconnected devices will enable collection of large amounts of data that can be further processed and used in a variety of areas, such as logistics, healthcare, energy, etc. Furthermore, this technology can be used in the so-called "smart homes" (Simtinger and Zhong, 2020).

The Internet of Services (IoS) is a term used to link web/internet-based services and realworld services that are described using the Unified Service Description Language (USDL).

Big Data is the term used for a massive volume of structured and unstructured data, which is so large that it is difficult to process using traditional databases and software technology. The sources of big data include data from the use of the internet, data from various sensors monitoring production processes and logistics of production plants, social networks, intelligent sensors, CRM systems, telescopes, satellite observations, tomographs, gene analyzers, or security cameras. The processing of this data in industry leads primarily to optimization of its own production, related services, support activities, and distribution.

Cloud Computing is an internet-based model of using computer technology. It can be defined as the provision of services or programs stored on servers on the internet, to which users have access through a web browser or a software client and can thus use their data from anywhere.

Additive Manufacturing is a process of three-dimensional object creation using a specific device. The product is created by gradual application of thin layers on each other and the printing itself is controlled by control electronics based on a program template. Unlike 3D printing, additive production is a term for the process in which the final product is created, not just for the prototype itself. (Siekelova et al., 2019)

Within the development of Industry 4.0, interconnection between computers can be assumed. Computers should be able to make their own decisions without human assistance. It is the combination of CPS, IoT (Internet of Things), and IoS (Internet of Services) that makes 
Industry 4.0 and the possibility of a smart factory a reality. As a result of development of smart machines, which are becoming smarter thanks to their ever-increasing access to data, our factories should be more efficient and productive and less wasteful. It leads to the real power of Industry 4.0. (Siekelova and Podhorska, 2019)

The issue of Industry 4.0 is very topical. Many authors dealt with this issue $n$ their studies. Chen (2020) explores how small and medium-sized enterprises (SMEs) in Taiwan employ technology to participate in global supply chains to respond to the Fourth Industrial Revolution. Rafael et al. (2020) state that Maturity Models (MM) can be very useful, since they help to evaluate the initial state of a company and to plan a development road map. Over the last few years, several MMs geared towards Industry 4.0 have been created and released, some of which are specifically aimed at certain sectors. However, there is none especially developed for an industry of such vital importance as the MT sector. His article presents a new MM adapted to this type of company, with a design based on previously validated developments and standards relating to MM. Dressler and Paunovic (2020) state that the current Industry 4.0 theoretical base is weak, impeding further digital transformation of some industries. They focused on the wine industry. Veile et al. (2020) examined how Industry 4.0 reshapes future buyer-supplier relationships. The issue of Industry 4.0 has been discussed by many other authors as well. (Madarasz and Szikora, 2018; Schott et al., 2020; Karadayi-Usta, 2020; Oliveira et al. 2020; Braglia et al., 2020; Liu et al., 2020; Li, 2020; Xu, 2020; Simetinger and Zhang, 2020; etc.)

\section{Methodology}

The authors use secondary data to examine the readiness of the Visegrad Four countries for the challenges related to the Fourth Industrial Revolution - Industry 4.0. The Digital Economy and Society Index (DESI) is a composite index that summarises the relevant indicators of Europe's digital performance and tracks the evolution of EU member states in digital competitiveness. The DESI 2020 reports are based on 2019 data. The United Kingdom is still included in the 2020 DESI, and EU averages are calculated for 28 member states. DESI is made up of five dimensions, namely connectivity, human capital, use of internet, integration of digital technology, and digital public services. Each dimension is defined by the sub-dimensions listed below.

The authors also use z-score to examine the readiness of the V4 for the challenges related to the Fourth Industrial Revolution - Industry 4.0.

$$
z-\text { score }=\frac{X-\mu}{\sigma}
$$

Where:

X value

$\mu \quad$ mean

$\sigma \quad$ standard deviation

The results currently show which countries achieve the best results in terms of the Drivers of Production values when compared to the GDP per capita. To see how each country is doing compared to the mean value of the respective indicators, z-scores were calculated for each of them. Hayes (2019) defines this method as a numerical measurement used in statistics of a value's relationship to the mean (average) of a group of values, measured in terms of standard deviations from the mean. If a z-score is 0 , it indicates that the data point's score is identical to the mean score. A z-score of 1.0 would indicate a value that is one standard deviation distant from the mean. Z-scores may be positive or negative, with a positive value indicating the score is above the mean and a negative score indicating it is below the mean. 


\section{Results and Discussion}

\subsection{Selected European initiatives responding to industry 4.0}

Several national initiatives responding to Industry 4.0 have been launched across Europe in recent years. The European Commission, together with the member states and industry, have set up a governance framework to mobilize stakeholders, exchange best practices, and support the coordination of EU and national initiatives. The European Platform of national initiatives, launched in March 2017, is at the core of the coordination effort. The Platform plays an essential role in the roll-out of industry digitalization across Europe. The basic functions of the platform are experience sharing, collaboration and joint investment triggering, exploration of common approaches to regulatory problems, and exchange of means for re-skilling of the workforce (European Commission, 2018). Information about individual national initiatives can be found at the European Platform of national initiatives. The first European Industry 4.0 initiative was launched in Germany. The purpose of the national initiatives is to regulate realization of Industry 4.0 and its consequences. Almost every member state of the European Union has its own national initiative. Other economic powers, led by the USA, China, and Japan, also have their initiatives. In this chapter, selected national initiatives will be briefly described.

\subsubsection{Slovakia: The smart industry initiative}

The SMART INDUSTRY initiative for the Slovak Republic was presented at a high-level conference in March 2016 by the Slovak Ministry of Economy. This initiative was inspired by Germany's and Netherlands' initiatives. The SMART INDUSTRY initiative deals with the low levels of digital awareness in Slovak companies. It is focused on bringing the nation's business community, mainly industrial entities, closer to the principles of Industry 4.0. A summary of Slovakia's SMART INDUSTRY initiative can be seen in Table 1.

Table 1: Summary of Slovakia's SMART INDUSTRY policy initiative

\begin{tabular}{|c|c|}
\hline Elements & Description \\
\hline Policy Levers(s) & Rather top-down approach; public financing; technology-oriented. \\
\hline Funding Model & $\begin{array}{l}\text { Funding model based on already-existing Operation Programs; European funds and exploring } \\
\text { further innovative funding options. }\end{array}$ \\
\hline Target Audience(s) & Industry, SMEs, R\&D organizations, education providers and civil society. \\
\hline $\begin{array}{l}\text { Concepts and Focus } \\
\text { Areas }\end{array}$ & $\begin{array}{l}\text { Improving awareness and cooperation; R\&D activities; Factories of the Future, access to } \\
\text { finance; labor market, education and skills; legislative framework adjustments encouraging } \\
\text { innovations. }\end{array}$ \\
\hline Key Drivers & $\begin{array}{l}\text { Active involvement of policy makers from key ministries; industry and business representatives, } \\
\text { research and education institutions. }\end{array}$ \\
\hline Key Barriers & Slow start, tight timeframe and no clear funding scheme. \\
\hline $\begin{array}{l}\text { Implementation } \\
\text { Strategy }\end{array}$ & $\begin{array}{l}\text { Creation of the Action Plan by a team of experts, awareness-rising activities, use of Smart } \\
\text { Industry Platform (working group of different experts) as a coordinating body for the } \\
\text { implementation process. }\end{array}$ \\
\hline Results Achieved & No results available, the initiatives is still in the early implementation stages. \\
\hline Budget & $\begin{array}{l}\text { No additional budget earmarked for the purpose of this initiatives; makes use of already existing } \\
\text { financing mechanisms. }\end{array}$ \\
\hline Uniqueness Factor & Creation of coordinating body composed of the multidisciplinary experts to implement initiative. \\
\hline $\begin{array}{l}\text { Value Added for } \\
\text { Policy-Makers }\end{array}$ & $\begin{array}{l}\text { Active cooperation with different stakeholders, more awareness raising of the initiatives and } \\
\text { challenges in the public sphere. }\end{array}$ \\
\hline Expected Impact & $\begin{array}{l}\text { Modernization and digitization of Slovak industry and companies; overall increase in } \\
\text { competitiveness of Slovak industry. }\end{array}$ \\
\hline
\end{tabular}

Source: Slovakia's SMART INDUSTRY, 2018

The initiative was prepared in the hope it would help Slovak entities adapt to Industry 4.0 related changes. The initiative is focused on SMEs operating in traditional industries with lack of resources to adapt to global trends compared to larger firms. One of the key barriers in the 
implementation process was the initial slow start to the Platform's activities. Implementation of the SMART INDUSTRY initiative requires active approach of all key stakeholders to develop action plans. At the beginning, it was difficult to find consensus among stakeholders in the formulation of an action plan in cooperation with a team from the Slovak Ministry of Economy. Another barrier is defined by the lack of "fresh funds".

\subsubsection{Poland: The initiative for polish industry 4.0 - the future industry platform}

The Initiative for Polish Industry 4.0 - The Future Industry Platform responds to economic challenges related to The Fourth Industrial Revolution. The Future Industry Platform was announced as part of the Responsible Development Plan, also known as the "Morawiecki Plan", prepared by the Polish Ministry of Finance and Development in 2016. The then Minister of Finance Morawiecki stated that the responsible development plan is the backbone of the country's economic policy. The then Minister of Finance Morawiecki stated that the responsible development plan was the backbone of the country's economic policy. A summary of the Initiative for Polish Industry 4.0 - The Future Industry Platform can be seen in Table 2.

Table 2: Summary of the Initiative for Polish Industry 4.0 - The Future Industry Platform

\begin{tabular}{|c|c|}
\hline Elements & Description \\
\hline Policy Levers(s) & $\begin{array}{l}\text { Financially backed by the state - and by the private sector in the long term, bottom- up, industry } \\
\text { led approach combining technological transformation and business development. }\end{array}$ \\
\hline Funding Model & $\begin{array}{l}\text { Public fund will serve to boost private investment and to shape market capabilities for the } \\
\text { industrial transformation. }\end{array}$ \\
\hline Target Audience(s) & $\begin{array}{l}\text { Public and private stakeholders interested in the field of industry transformation: mostly SMEs } \\
\text { as well as domestic } 4.0 \text { solutions suppliers, academia, research organizations, etc. }\end{array}$ \\
\hline $\begin{array}{l}\text { Concepts and Focus } \\
\text { Areas }\end{array}$ & $\begin{array}{l}\text { Raising awareness, competence building, infrastructure development, SME support, actions } \\
\text { focused across multiple industrial sectors }\end{array}$ \\
\hline Key Drivers & $\begin{array}{l}\text { Competence Centers and network of experts aiming to create a "critical mass" for an effective } \\
\text { implementation of the digital transformation strategy. }\end{array}$ \\
\hline Key Barriers & $\begin{array}{l}\text { Low awareness level among SMEs, long legislative process and the complexity of establishing a } \\
\text { mechanism supporting SMEs financially in implementing new technologies. }\end{array}$ \\
\hline $\begin{array}{l}\text { Implementation } \\
\text { Strategy }\end{array}$ & $\begin{array}{l}\text { The implementation will be carried out following three phases: } 1 \text {. Preparation; } 2 \text {. Formation of } \\
\text { the Future Industry Platform; } 3 \text {. Operational phase. }\end{array}$ \\
\hline Results Achieved & $\begin{array}{l}\text { It is expected that the initiative will boost the innovativeness of domestic suppliers of the digital } \\
\text { solutions, resulting in an increase of the competitiveness of the Polish industrial sector. }\end{array}$ \\
\hline Budget & The Industrial Platform will have two budgets; EU funds will be used for market transformation. \\
\hline Uniqueness Factor & $\begin{array}{l}\text { As the Government cooperates closely with a prior private initiative in this field, the Platform is } \\
\text { expected to meet the expectations and needs of the private sector. }\end{array}$ \\
\hline $\begin{array}{l}\text { Value Added for } \\
\text { Policy-Makers }\end{array}$ & $\begin{array}{l}\text { A competence center pilot project will ensure proper evaluation mechanisms are in place before } \\
\text { the replication of the initiative in other Polish regions. }\end{array}$ \\
\hline Expected Impact & $\begin{array}{l}\text { Improve the industrial transformation capabilities of SMEs and provide a boost tothe Polish } \\
\text { economy. }\end{array}$ \\
\hline
\end{tabular}

Source: Initiative for Polish Industry 4.0 - The Future Industry Platform, 2018

Compared to the Slovakia's SMART INDUSTRY initiative, the Initiative for Polish Industry 4.0 is more detailed. This initiative also contains the activities covered, as well as their expected results. The objectives of the government for 2020 include:

- increasing investment to over $25 \%$ of GDP;

- increasing the share of R\&D expenditure to $2 \%$ of GDP;

- increasing the number of medium-sized and large enterprises to over 22,000;

- increasing foreign direct investment in Poland by $70 \%$;

- improving the growth rate of industrial production;

- setting the GDP per capita of Poland to $79 \%$ of the EU average (Initiative for Polish Industry 4.0 - The Future Industry Platform, 2018). 


\subsubsection{Czech Republic: "Průmysl 4.0"}

The Czech initiative responding to Industry 4.0 related changes was presented during the 57th International Engineering Fair in Brno in September 2015. Prümysl 4.0 was approved by the Government of the Czech Republic later in August 2016. The implementation of Prumysl 4.0 should lead to more efficient manufacturing, meaning faster, cheaper, and resourceeffective production. A summary of Průmysl 4.0 can be seen in Table 3.

Table 3: Summary of the Prümysl 4.0 policy initiative

\begin{tabular}{|c|c|}
\hline Elements & Description \\
\hline Policy Levers(s) & Bottom-up approach, public financing, orientation towards skills. \\
\hline Funding Model & $\begin{array}{l}\text { Funding model based on already existing operational programmes of the involved ministries and } \\
\text { the Technological Agency of the Czech Republic. }\end{array}$ \\
\hline Target Audience(s) & Policy makers, private sector, R\&D organizations, industry associations, academia. \\
\hline $\begin{array}{l}\text { Concepts and Focus } \\
\text { Areas }\end{array}$ & $\begin{array}{l}\text { Timely response to the market and industry changes by creating a flexible education system; } \\
\text { adapting the labour market and regulatory framework. }\end{array}$ \\
\hline Key Drivers & $\begin{array}{l}\text { Active involvement of policy makers from key Ministries, representatives from industry, } \\
\text { business, research and education. }\end{array}$ \\
\hline Key Barriers & $\begin{array}{l}\text { Reluctance to change, insufficient knowledge of Industry 4.0, deficient coverage of broadband } \\
\text { connection in some regions. }\end{array}$ \\
\hline $\begin{array}{l}\text { Implementation } \\
\text { Strategy }\end{array}$ & $\begin{array}{l}\text { A team of experts involved in the creation of the Action Plans, dissemination activities and } \\
\text { awareness raising already in place. }\end{array}$ \\
\hline Results Achieved & No results available, the initiative is still in the early stage of implementation. \\
\hline Budget & No extra budget earmarked for the purposes of this initiative. \\
\hline Uniqueness Factor & $\begin{array}{l}\text { Addressing the topic as an overall societal challenge beyond industry; Multidisciplinary } \\
\text { approach actively involving key stakeholders. }\end{array}$ \\
\hline $\begin{array}{l}\text { Value Added for } \\
\text { Policy-Makers }\end{array}$ & $\begin{array}{l}\text { Active cooperation with stakeholders in the entire process facilitates identification needs, } \\
\text { expectations and feedback in form of a bottom-up approach. }\end{array}$ \\
\hline Expected Impact & Maintaining and boosting the competitiveness of the Czech Republic. \\
\hline
\end{tabular}

Source: Prümysl 4.0, 2017

The Czech Minister of Industry stated that Průmysl 4.0 is a way to maintain Czech competitiveness. No extra budget was earmarked for the purposes of this initiative. Public funding is based on the financial tools already in place. There are operational programs and programs of the ministries and the Technical Agency to support related projects. Potential sources of financing included the then planned National Innovation Fund, as well as Trio, Gama, and Epsilon - programs administrated by ministries. No model for private financing is considered. It can be considered as a weakness, as can be the incomplete high-speed internet coverage. The main identified threats include the gap between industry and qualifications or cyber terrorism.

\subsubsection{Hungary: PAR 4.0 National Technology Platform}

The national initiative responding to the Fourth Industrial Revolution is based on the "Irinyi Plan"- a recent industrialization strategy. The PAR 4.0 National Technology Platform was launched in the spring of 2016. A summary of thePAR 4.0 National Technology Platform can be seen in Table 4.

Table 4: Summary of the PAR 4.0 National Technology Platform policy initiative

\begin{tabular}{ll}
\hline Elements & Description \\
\hline Policy Levers(s) & $\begin{array}{l}\text { Bottom-up approach, public financing, equally orientated towards technology and infrastructure } \\
\text { and skills. }\end{array}$ \\
Funding Model & $\begin{array}{l}\text { Simple public funding model under negotiations, a possibility to secure private financing } \\
\text { through introduction of membership fees. }\end{array}$ \\
Target Audience(s) & $\begin{array}{l}\text { Policy makers, private sector, R\&D organizations, industry associations, universities, social } \\
\text { circles, business. }\end{array}$
\end{tabular}




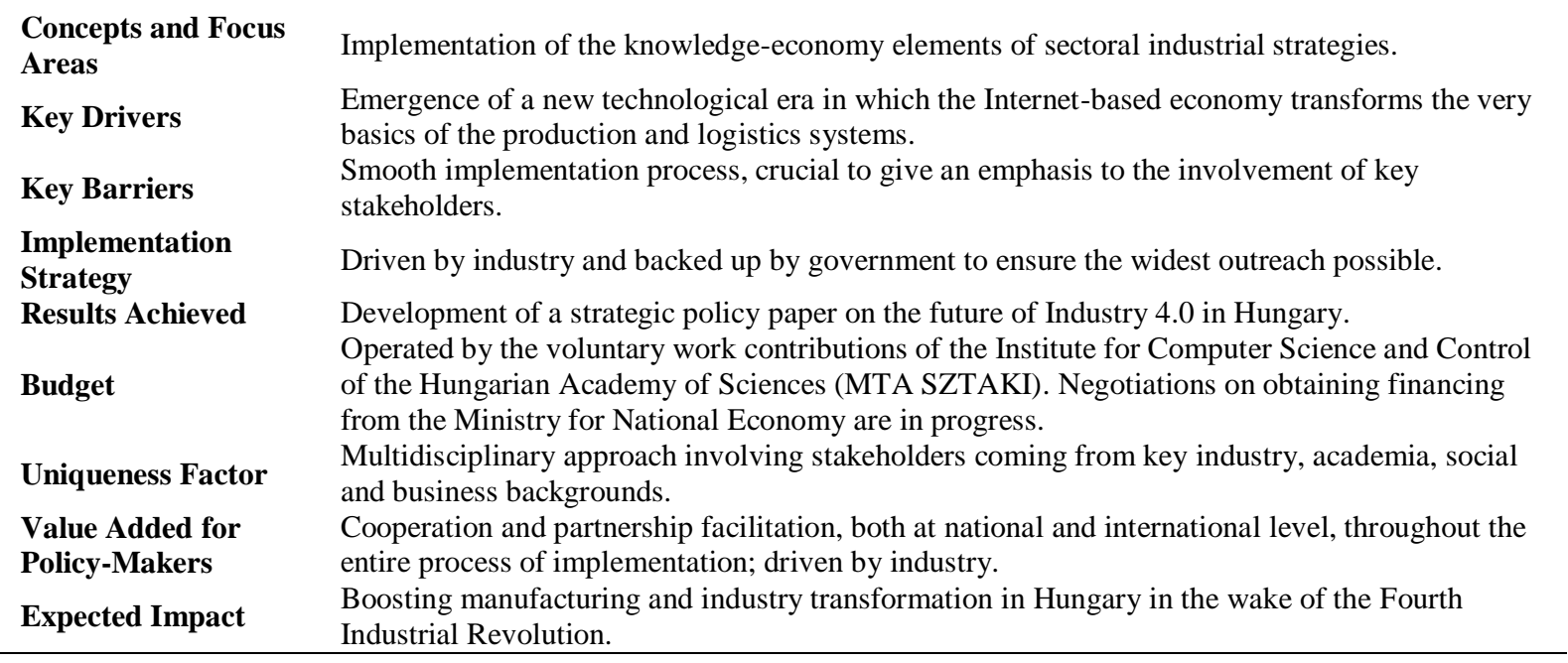

Source: The PAR 4.0 National Technology Platform, 2017

The main objectives are defined as follows:

- increase the industrial output to GDP ratio from the current $23.5 \%$ to $30 \%$ by 2020 ;

- increase the level of R\&D expenditures to $1.8 \%$ of the GDP by 2020 ;

- reinforce the growth, export, and innovation potential of domestic companies;

- decrease standardized low-skill activities;

- increase high-skill activities, embracing planning, control and IT-related tasks (The Industry 4.0 National Technology Platform, 2017).

Lack of transferability across highly industrialized Western European countries was defined as the main threat. The Hungarian strategy does not contain a model for private financing.

\section{The digital economy and society index}

As mentioned above, the Digital Economy and Society Index (DESI) monitors Europe's overall digital performance and tracks the progress of EU countries in digital competitiveness. The following figures 1-5 show comparison of DESI score by five indicators between the Czech Republic, Slovakia, Hungary, Poland, and the European Union. 


\section{Figure 1: DESI by Connectivity}

The Digital Economy and Society Index by Connectivity

12,50

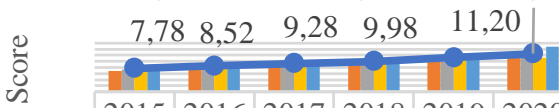

\begin{tabular}{|l|l|l|l|l|l|}
2015 & 2016 & 2017 & 2018 & 2019 & 2020 \\
\hline
\end{tabular}

\begin{tabular}{|l|l|l|l|l|l|l|}
\hline Poland & 6,96 & 7,66 & 8,81 & 9,85 & 10,70 & 12,80 \\
\hline
\end{tabular}

\begin{tabular}{|l|l|l|l|l|l|l|l|}
\hline Slovakia & 7,22 & 7,96 & 9,02 & 9,48 & 9,91 & 11,90 \\
\hline
\end{tabular}

\begin{tabular}{|c|c|c|c|c|c|c|c|}
\hline $\begin{array}{c}\text { Czech } \\
\text { Republic }\end{array}$ & 8,10 & 8,68 & 8,99 & 9,85 & 10,90 & 11,20 \\
\hline
\end{tabular}

\begin{tabular}{c|c|c|c|c|c|c|}
\hline Hungary & 7,35 & 8,52 & 9,35 & 10,30 & 11,50 & 14,90
\end{tabular}

\begin{tabular}{c|c|c|c|c|c|c|} 
- $\begin{array}{c}\text { European } \\
\text { Union }\end{array}$ & 7,78 & 8,52 & 9,28 & 9,98 & 11,20 & 12,50
\end{tabular}

Poland Slovakia

Czech Republic Hungary

$\longrightarrow$ European Union

Source: Authors based on DESI data

Figure 3: DESI by Use of Internet

The Digital Economy and Society Index by Use of Internet

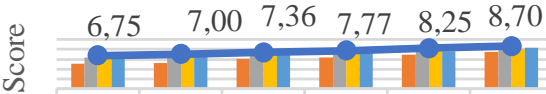

\begin{tabular}{|l|l|l|l|l|l|}
2015 & 2016 & 2017 & 2018 & 2019 & 2020 \\
\hline
\end{tabular}

\begin{tabular}{|c|c|c|c|c|c|c|}
\hline Poland & 5,01 & 5,19 & 6,02 & 6,32 & 6,87 & 7,45 \\
\hline Slovakia & 6,42 & 6,31 & 7,07 & 7,31 & 7,70 & 8,00 \\
\hline $\begin{array}{l}\text { Czech } \\
\text { Republic }\end{array}$ & 6,39 & 6,45 & 6,74 & 7,15 & 7,69 & 8,12 \\
\hline Hungary & 6,90 & 7,08 & 7,27 & 7,42 & 7,68 & 8,38 \\
\hline $\begin{array}{c}\text { European } \\
\text { Union }\end{array}$ & 6,75 & 7,00 & 7,36 & 7,77 & 8,25 & 8,70 \\
\hline
\end{tabular}

Poland Slovakia

Czech Republic $\quad$ Hungary

-European Union

Source: Authors based on DESI data
Figure 2: DESI by Human Capital

The Digital Economy and Society Index

by Human Capital

12,32

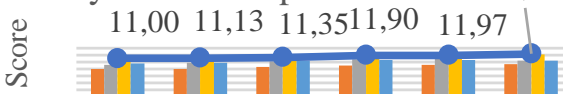

\begin{tabular}{|l|l|l|l|l|l|}
\hline 2015 & 2016 & 2017 & 2018 & 2019 & 2020 \\
\hline
\end{tabular}

\begin{tabular}{|l|l|l|l|l|l|l|}
\hline Poland & 7,92 & 8,01 & 8,62 & 9,06 & 9,21 & 9,32 \\
\hline
\end{tabular}

\begin{tabular}{|l|l|l|l|l|l|l|}
\hline Slovakia & 9,24 & 9,74 & 10,15 & 10,74 & 11,05 & 10,45 \\
\hline
\end{tabular}

\begin{tabular}{|c|c|c|c|c|c|c|}
\hline $\begin{array}{c}\text { Czech } \\
\text { Republic }\end{array}$ & 11,21 & 11,14 & 10,70 & 11,26 & 11,20 & 12,16 \\
\hline
\end{tabular}

\begin{tabular}{|c|c|c|c|c|c|c|}
\hline Hungary & 9,61 & 9,87 & 10,31 & 10,63 & 10,53 & 10,46 \\
\hline
\end{tabular}

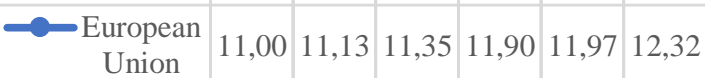

Poland Slovakia

Czech Republic Hungary

- European Union

Source: Authors based on DESI data

Figure 4: DESI by Integration of Digital Technology

The Digital Economy and Society Index by Integration of Digital Technology

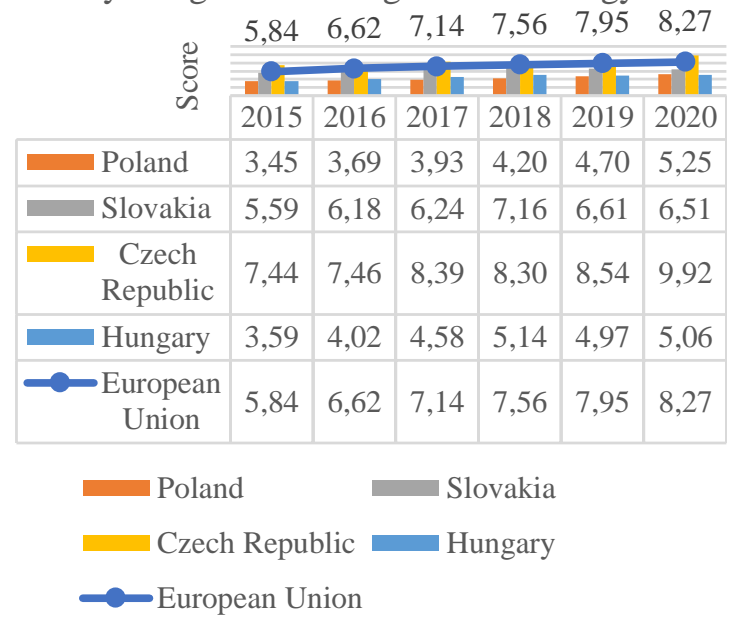

Source: Authors based on DESI data 
Readiness for industry 4.0 related changes:

A case study of the Visegrad four

Authors: Kornelia Lazanyi, Maya Lambovska

Figure 5: DESI by Digital Public Service

\begin{tabular}{|c|c|c|c|c|c|c|}
\hline The & $\begin{array}{c}\text { igital } \\
7,53\end{array}$ & $\begin{array}{c}y \text { and } \\
8,13\end{array}$ & $\begin{array}{c}\text { Index } \\
8,69\end{array}$ & $\begin{array}{c}\text { ital P } \\
9,28\end{array}$ & $\begin{array}{l}\text { rvice } \\
10,05\end{array}$ & 10,80 \\
\hline ठํ & $\mathrm{C}$ & $\rightarrow$ & 2 & & & \\
\hline & 2015 & 2016 & 2017 & 2018 & 2019 & 2020 \\
\hline Poland & 7,96 & 7,99 & 8,13 & 8,24 & 9,23 & 10,11 \\
\hline Slovakia & 4,59 & 4,66 & 6,08 & 7,20 & 7,61 & 8,34 \\
\hline Czech Republic & 4,96 & 5,63 & 7,19 & 8,12 & 8,98 & 9,36 \\
\hline Hungary & 4,23 & 4,33 & 5,28 & 6,54 & 7,61 & 8,67 \\
\hline -European Union & 7,53 & 8,13 & 8,69 & 9,28 & 10,05 & 10,80 \\
\hline
\end{tabular}

Source: Authors' elaboration based on DESI data

The connectivity dimension is calculated as the weighted average of the five sub-dimensions, namely fixed broadband take-up (25\%), fixed broadband coverage $(25 \%)$, mobile broadband $(35 \%)$, and broadband price index (15\%). The biggest progress within fixed broadband take-up has been made in Hungary and in Poland. On the other hand, the overall level of this indicator is the lowest in Poland. Between 2015-2020, the progress of this indicator in the Czech Republic and Slovakia was not so significant. Significant progress in fixed broadband coverage has recently been made in Poland. The level of this indicator is higher compared to the European Union. Hungary and Slovakia have almost the same level of this indicator. The lowest level of this indicator is in the Czech Republic. The biggest progress within the third indicator-mobile broadband - has been made in Hungary and in Slovakia. The Czech Republic has the lowest level of this indicator. The progress within the broadband price index is not significant. The highest level of this indicator has been achieved in Poland. The lowest level of this indicator is found in the Czech Republic. The level of this indicator in Hungary is very similar to the European Union. Slovakia has a higher level of this indicator than the Czech Republic, but lower than Hungary.

The Human Capital dimension is calculated as the weighted average of the two subdimensions, namely Internet User Skills (50\%) and Advanced Skills and Development (50\%). Between 2018-2019, Slovakia had the highest level of the first indicator-internet user skills. For 2020, the level of this indicator is lower than in the European Union and in the Czech Republic. The lowest level is found in Poland. Significant progress within advanced skills and development has been made in the Czech Republic. The level of this indicator is the same as in the European Union. A lower level of this indicator is found in Hungary and the lowest level in Poland and Slovakia.

The Internet dimension is calculated as the weighted average of the three sub-dimensions, namely Internet Use (25\%), Activities Online (50\%), and Transactions (25\%). The Czech Republic has the highest level of the internet use indicator. A lower level is found in Slovakia, followed by Hungary, with the lowest level in Poland. The Czech Republic, Poland, and Slovakia have very similar levels of the second indicator - activities online. This level is lower than in the European Union. The highest level of this indicator is found in Hungary, significantly higher than in the European Union. Significant progress in the third indicator has been made in Slovakia. The level of this indicator is higher in Slovakia than in the European Union. The level of the European Union is very similar to the Czech Republic. The lowest level of this indicator is found in Hungary, which declined significantly in this area in 2017. 
The Digital Technology dimension is calculated as the weighted average of the two subdimensions, namely Business digitization (60\%) and e-Commerce (40\%). Between 2015-2019, Slovakia had the highest level of business digitization (but not higher than the European Union). In 2020, the highest level of this indicator was found in the Czech Republic and the lowest level in Hungary. Significant progress within the e-Commerce indicator has been made in the Czech Republic, where the level of this indicator was the highest during 2015-2020. The lowest level of this indicator is found in Poland.

The Digital Public Services dimension is calculated by taking the score for e-Government. The highest level of the last indicator is found in Poland (but not higher than in the European Union), followed by the Czech Republic, Hungary, while the lowest level is found in Slovakia.

\section{Z-Score calculation}

Table 5 shows comparison of the two selected indicators, GDP per capita and the Drivers of Production dimension within the V4. The Drivers of Production indicator shows how well a country is positioned to embrace the 4th Industrial Revolution considering different factors such as technologies, innovations, human capital, global trade, investment, institutional framework, sustainable resources, and environmental demands.

Table 5: Z-Scores

\begin{tabular}{|c|c|c|c|c|c|}
\hline Country & $\begin{array}{l}\text { GDP per capita, } \\
\text { PPP (current } \\
\text { international } \\
\text { USD) }^{*}\end{array}$ & Z-Score & $\begin{array}{l}\text { Drivers of } \\
\text { Production }\end{array}$ & Z-Score & $\begin{array}{l}\text { Z-Score } \\
\text { Difference }\end{array}$ \\
\hline Slovakia & $32,574.80$ & -0.37 & 5.33 & -0.80 & $-0,43$ \\
\hline Czech Republic & $40,389.40$ & 1.49 & 6.01 & 1.10 & $-0,39$ \\
\hline Poland & $31,983.40$ & -0.51 & 5.83 & 0.59 & 1,1 \\
\hline Hungary & $31,578.80$ & -0.61 & 5.30 & -0.89 & $-0,28$ \\
\hline
\end{tabular}

Source: Authors' elaboration based on data from the World Bank and the World Economic Forum

* note: This indicator provides per capita values for gross domestic product (GDP) expressed in current international dollars converted by the purchasing power parity (PPP) conversion factor.

Since the data used, i.e., the GDP per capita and the WEF's Drivers of Production values, represent two entirely different data sets, the z-scores calculated for each of them would help us understand the position of each country relative to the mean value within each set. Thus, comparison of both sets is possible to see whether some countries perform above average in terms of the Drivers of Production values, while their GDP per capita is not up to par. Hence, subtraction of the respective z-scores was carried out (the WEF values z-score minus the GDP per capita values z-score), and the countries were sorted in descending order based on the zscores difference (see the last column).

\section{Conclusion}

The aim of the paper was an examination of readiness of the V4 countries for the changes connected with Industry 4.0.

The theoretical section of the paper focused on definition of industrial revolution, with a comparison of historical industrial revolutions focusing on the Fourth Industrial Revolution known as Industry 4.0.

The practical section of the paper focused on examination of readiness of the V4 countries for changes related to Industry 4.0. The national initiatives related to Industry 4.0 were described. For Slovakia, several barriers were mentioned: at the beginning, it was difficult to find consensus among stakeholders in formulating an action plan in cooperation with a team 
Readiness for industry 4.0 related changes:

A case study of the Visegrad four

Authors: Kornelia Lazanyi, Maya Lambovska

from the Slovak Ministry of Economy; another barrier was defined as the lack of "fresh funds". Compared to the Slovakia's SMART INDUSTRY initiative, the Initiative for Polish Industry 4.0 is more detailed. This initiative also contains the activities covered and their expected results. No model for private financing is considered a weakness in the Czech Republic, as is its incomplete high-speed internet coverage. The main threats were defined as the gap between industry and qualifications and cyber terrorism. Within Hungary, lack of transferability across highly industrialized Western European countries was defined as the main threat. The Hungarian strategy does not contain a model for private financing.

A z-score calculation was carried out to compare the preparedness of the V4 for Industry 4.0 related changes considering two selected indicators, GDP per capita and the Drivers of Production dimension. The results can be seen in Table 5 .

\section{References}

Amiti, M. (2001). Regional specialization and technological leapfrogging. Journal of Regional Science, 41(1), 149-172.

Baptista, R. (1999). The diffusion of process innovations: A selective review. International Journal of the Economics of Business, 6(1), 107-12.

Beaudoin, S. M. (2000). Current debates in the study of the industrial revolution. Magazine of History; Bloomington, 15(1), 7-13.

Braglia, M., Marrazzini, L., Padellini, L., \& Rinaldi, R. (2020). Managerial and industry 4.0 solutions for fashion supply chains. Journal of Fashion Marketing and Management, Early Access.

Brezis, E. S., Krigman, P. R., \& Tsiddon, D. (1993). Leapfrogging in international competition: A theory of cycles in national technological leadership. The American Economic Review, 83(5), 1211-1219.

Brezis, E. S., \& Tsiddon, D. (1998). Economic growth, leadership and capital flows: The leapfrogging effect. Journal of International Trade and Economic Development, 7(3), 261-277.

Cameron, R. E., \& Drabek, V. (1996). Stručné ekonomické dějiny světa: Od doby kamenné do současnosti. Victoria Publishing.

Diana, S. (2017). Magyarország mezőgazdaságának történelmi áttekintése. Tanulmánykötet-Vállalkozásfejlesztés a XXI. században VII., 580-601.

Digital Economy and Society Index, (2020). <https://digital-agenda-data.eu/>.

Dressler, M., \& Paunovic, I. (2020). Converging and diverging business model innovation in regional intersectoral cooperation-exploring wine industry 4.0. European Journal of Innovation Management, Early Access.

European Commission, (2018, November 6). Coordination of European, national \& regional initiatives. <https://ec.europa.eu/digital-single-market/en/coordination-european-national-regional-initiatives>.

European Commission, (2018, February). Poland: "Initiative for polish industry 4.0 - the future industry platform”.

<https://ec.europa.eu/growth/tools-databases/dem/monitor/sites/default/files/DTM_Poland\%20_vf.pdf>.

European Commission, (2017, May). Czech Republic: "Prümysl 4.0". <https://ec.europa.eu/growth/toolsdatabases/dem/monitor/sites/default/files/DTM_Prumys1\%2040_CZ\%20v3.pdf>.

European Commission, (2017, December). Hungary: “IPAR 4.0 National Technology Platform”. <https://ec.europa.eu/growth/tools-databases/dem/monitor/sites/default/files/DTM_IPAR_HU_v4.pdf>.

European Commission, (2018, February). Slovakia: Smart Industry. <https://ati.ec.europa.eu/sites/default/files/2020-05/Slovakia.pdf>.

Chen, C.L. (2020). Cross-disciplinary innovations by Taiwanese manufacturing SMEs in the context of industry 4.0. Journal of Manufacturing Technology Management, Early Access.

Jain, V., \& Ajmera. P. (2020). Modelling the enablers of industry 4.0 in the Indian manufacturing industry. International Journal of Productivity and Performance Management, Early Access.

Karadayi-Usta, S. (2020). An interpretive structural analysis for industry 4.0 adoption challenges. IEEE Transactions on Engineering Management, 67(3), 973-978.

Lazányi, K. (2016). Stressed Out by the Information and Communication technologies of the 21st Century. Science Journal of Business and Management, 4(1-1), 10-14.

Lazányi, K., Čepel, M., \& Bilan, S. (2017). Comparison of trust and social relations among students in Russian and Hungarian higher education. Economics \& Sociology, 10(4), 162-174.

Li, L. (2020). Education supply chain in the era of Industry 4.0. Systems Research an Behavioral Science, 37(4), $579-592$. 
Liu, Z.M., Xie, K.F., Li, L., \& Chen, Y. (2020). A paradigm of safety management in industry 4.0. Systems Research and Behavioral Science, 37(4), 632-645.

Madarasz, N., \& Szikora, P. (2018). Are we really prepared for full autonomy. In Available: 16th International Conference on Management, Enterprise and Benchmarking Proceedings: MEB (pp. 233-240).

Mezei, J. I., \& Lazányi, K. (2018). Are We Ready for Smart Transport? Analysis of Attitude Towards Public Transport in Budapest. Interdisciplinary Description of Complex Systems: INDECS, 16(3-A), 369-375.

Nazarov, D., \& Klarin A. (2020). Taxonomy of industry 4.0 research: Mapping scholarship and industry insights. Systems Research and Behavioral Science, 37(4), 535-556.

Oliveira, B. G., Liboni, L. B., Cezarino, L. O., Stefanelli, N. O., \& Miura, I. K. (2020). Industry 4.0 in systems thinking: From a narrow to a broad spectrum. Systems Research and Behavioral Science, 37(4), 593-606.

Rafael, L. D., Jaione, G. E., Lopez C., \& Serano, L. I. (2020). An industry 4.0 maturity model for machine tool companies. Technological Forecasting and Social Change, 159, 120203.

Schott, P., Lender, M., Eigner, I., \& Bodendorf, F. (2020). Case-based reasoning for complexity management in industry 4.0. Journal of Manufacturing Technology Management, Early Access.

Simetinger, F., \& Zhang, Z. (2020). Deriving secondary traits of industry 4.0: A comparative analysis of significant maturity models. Systems Research and Behavioral Science, 34(4), 663-678.

Siekelova, A., Kovacova, M., Adamko, P., \& et al. (2019). Profit management as an instrument for SMEs developing: the case for Slovakia. Marketing and Management of Innovations, (3), 285-296.

Siekelova, A., \& Podhorska, I. (2019). Earnings indicators under the condition of globalization. Proceedings of the $19^{\text {th }}$ International Scientific Conference Globalization and Its Socio-Economic Consequences Sustainability in the Global-Knowledge Economy, 74, 01031. University of Zilina, Slovakia.

The World Bank, (2018). GDP per capita, PPP (current international \$). <https://data.worldbank.org/indicator/NY.GDP.PCAP.PP.CD>.

Veile, J. W., Schmidt, M. C., Muller, J. M., \& Voigt, K. I. (2020). Relationship follows technology! how industry 4.0 reshapes future buyer-supplier relationships. Journal of Manufacturing Technology Management, Early Access.

World Economic Forum, (2018). Readiness for the Future of Production Report 2018. <http://www3.weforum.org/docs/FOP_Readiness_Report_2018.pdf>.

$\mathrm{Xu}, \mathrm{L}$. D. (2020). The contribution of systems science to industry 4.0. Systems Research and Behavioral Science, 34(4), 618-631.

Yunus, E. N. (2020). The mark of industry 4.0: How managers respond to key revolutionary changes. International Journal of Productivity and Performance Management, Early Access.

Zheng, Y. S. (2013). The research on the applications and trends of the information communication technology in the information society. Applied Mechanics and Materials, 321-324. 